\title{
Zbornik radova 2. hrvatskog kongresa o ruralnom turizmu s međunarodnim sudjelovanjem, "Koncepcija dugoročnog razvoja ruralnog turizma", Mali Lošinj, 21. - 25. travnja 2010., Hrvatski farmer, Zagreb 2010., I. i II. dio 718 str.
}

Preuzevši identičnu koncepciju istovremeno tiskanog "Zbornika radova Prvog kongresa o ruralnom turizmu", "Zbornik radova Drugog kongresa" također je podijeljen na cjeline, njih šest, jer su odijeljeni znanstveni i stručni radovi. Zbog velikog broja tekstova, ovaj "Zbornik radova" podijeljen je u dva sveska.

U prvom svesku objavljeni su tekstovi "Uvodnih izlaganja" i "Znanstveni radovi". "Uvodna izlaganja" čine četiri teksta kojima se predstavlja aktualno okruženje koje utječe na promišljanje dugoročnog razvoja hrvatskog turizma, pa tako i ruralnog, koji uglavnom ostaju taoci jedine brige za "pripremu iduće sezone". S pravom je istaknuto da je u takvom okruženju bespredmetno raspravljati o tome kakav ruralni turizam želimo u razdoblju između 2030. i 2040. godine. Potom, pregledno je izloženo stanje ruralnog turizma u Republici Hrvatskoj u posljednje dvije i pol godine, od Prvog hrvatskog kongresa o ruralnom turizmu održanog 2007. godine do danas, s kritičkim osvrtom na postignute rezultate, navedeni su i obrazloženi razlozi neispunjavanja pojedinih zaključaka, te smjernice i aktivnosti za daljnji održivi razvoj ruralnog prostora. Uvodni članak koji navodi na razmišljanje onaj je o analizi današnjeg agroturizma, jer skreće pozornost da je nužno propitati njegov daljnji opstanak i razvoj kao originalnog načina turističke ponude prema principu stila života. U tom smislu predlaže se radikalni zaokret u cilju odvajanja agroturizma kao ponude koja nudi stil života domaćina (očuvanu tradiciju prilagođenu suvremenim uvjetima), oživljavanje poljoprivrede i "pravi" život agroturizma koji treba biti potpomagan konkretnim potporama, jer će, u suprotnom, nestati. U posljednjem tekstu predstavljena je međunarodna organizacija ECOVAST, Europsko vijeće za sela i male gradove, kao aktivna udruga koja promiče očuvanje baštine uz cjeloviti razvoj ruralnog područja, što uključuje i razvoj ruralnog turizma.

Cjelina "Znanstveni radovi" sastoji se od 30 tekstova koji su "pokrili" sve četiri tematske cjeline Kongresa: "Marketing i brendiranje ruralnog turizma", "Ruralni prostor kao ruralna turistička destinacija", "Uloga hrane u razvoju ruralnog turizma" i "Turistički multisektorski klasteri u ruralnom prostoru". Riječ je o znanstvenim radovima koji na različite načine dotiču teme koje su raspravljane na Kongresu, 
oni sadrže bogatstvo numeričkih i grafičkih podataka, a autori su im, uglavnom, iz znanstvenih institucija. Zamjetno je da se veći broj znanstvenih tekstova bavi ulogom hrane, koja je prepoznata kao vodeća u razvoju ruralnog turizma, jer upravo nju vlasnici agroturizma nude svojim korisnicima. Slijedom rezultata recentnih istraživanja pokušalo se pokazati da na formiranje gastronomskog identiteta pojedinog ruralnog područja, odnosno regije, utječu povijesne okolnosti, konfiguracija tla, ali i turizam i politika, kako to pokazuju pojedini gastronomski simboli regija kao što su tartufi, maslinovo ulje, vino, i drugi. Upravo oni imaju funkciju privlačenja turista da provedu godišnji odmor baš u tim regijama, pa se zaključuje da hrana čini važan segment "paketa" ruralne turističke ponude neke regije. Zatim, više radova, temeljem terenskih analiza, donosi prikaze s osvrtima o stanju ruralnog turizma u pojedinim dijelovima Hrvatske, koji su raskrili specifične rezultate, a temeljem njih izdvojena su najvrijednija zajednička rješenja. Pojedini radovi obradili su neke od većih izazova u razvoju ruralnog turizma, na primjer kako učinkovito upravljati ruralnom turističkom destinacijom, nudeći kao rješenje razne modele, primjerice javno-privatno partnerstvo. U nekim, pak, radovima analizirani su do sada postignuti rezultati razvoja pojedinih oblika ruralnog turizma ("etno-sela", vinske ceste), koji su uspoređeni sa sličnima na širem prostoru, iz čega slijede šire primjenjive preporuke i zaključci. U nekoliko tekstova pozornost je posvećena sve izraženijem trendu ekološke poljoprivrede u funkciji razvoja ruralnog turizma, što navodi na prepoznavanje ekoloških seljačkih gospodarstava kao kanala distribucije turističkih usluga u ruralnom prostoru. Prostornom planiranju u ruralnom turizmu također je dana važnost. Obrađen je na način da se skrenula pozornost bitnosti prostornog planiranja u razvoju ruralnog turizma, jer se, u suprotnom, mogu izazvati negativne posljedice u prostoru i okolišu, a upozoreno je i na "rurizam" kao posebnu disciplinu u uređivanju ruralnog prostora. Potom, proučena je i uloga znanosti u podizanju kapaciteta za razvoj ruralnih područja, kao i nužnost obrazovanja u ruralnom turizmu. S obzirom na specifičnosti ruralnog turizma, obrazovanje za njegov razvoj ima posebno važno mjesto i treba ustrajati na njegovoj suvremenoj koncepciji koja se mora temeljiti na poduzetničkom pristupu uz cjeloživotno obrazovanje. Obrada teme marketinga u ruralnom turizmu pokazala je da je nužna marketing strategija ruralnog turizma temeljem koje bi se ostvario i humanistički sadržaj turizma zaštitom i unaprjeđenjem ruralnih prostora, posebno graditeljskih vrijednosti. Naposljetku, radovi koji su raspravljali o promociji u ruralnom turizmu potvrdili su da je ona, uz osobno iskustvo, jedan od najvažnijih segmenata stvaranja ali i mijenjanja imidža određenog ruralnog kraja/područja.

Prva cjelina drugog sveska "Zbornika" su "Stručni radovi" koja "broji" 23 članka. Oni obrađuju zaista veliki broj različitih tema vezanih za ruralni turizam. Mnogi od njih sadrže dragocjene podatke i poglavito se ističu svojom dokumentarističkom vrijednosti. Mogu poslužiti kao temelj za buduća stručna, ali i znanstvena istraživanja, a posebno onima koji će pripremati strateške odluke o budućem razvoju hrvatskog ruralnog turizma i uređenju pripadajućeg ruralnog prostora. Tako se kroz tekstove, primjerice, analiziraju globalne promjene u shvaćanju turizma s više stručnih aspekata, koje osobito određuju okvir razvoja ruralnog turizma. Potom, analizira se turistička resursna osnova ruralnog prostora s naglaskom na njezinoj 
atrakcijskoj komponenti, a pozornost se posvetila i etnografskoj komponenti turističke atrakcijske osnove ruralnih prostora. S različitih motrišta analizirana je problematika ruralne turističke destinacije, zatim razvoj turizma u pojedinim županijama, pojedini segmenti u politici ruralnog razvoja, pojedinačni problemi, aspekti, turistički proizvodi, i drugo.

U cjelinu "Studije slučaja" uvršteno je 10 radova, poglavito primjera dobre prakse, a riječ je o standardnim opisima obrađivanog predmeta/problema ili, pak, o doslovnim primjerima dobre prakse, kao i onima međunarodne suradnje na razvijanju ruralnog prostora s naglaskom na ruralnom turizmu. Te teme, uglavnom, zastupljene su i u cjelini "Strani radovi", s ukupno 19 tekstova, među kojima su i oni o aktivnostima pojedinih pokreta i organizacija, obrazovanju i edukaciji, dok posebnu, završnu cjelinu, čine "Sažeci" autora koji do tiskanja "Zbornika" nisu dostavili radove.

Možda bi se kao nedostatak ovoga, po broju radova i stranica, impresivnog "Zbornika" moglo smatrati grupiranje tekstova prema njihovoj znanstvenoj klasifikaciji, umjesto tematskoj, čime bi se dobile artikuliranije, zaokruženije i preglednije cjeline, iz kojih bi se susljednije mogli izvlačiti zaključci, kao i izostanak lektorskog i korektorskog rada osobito zamjetnog u pojedinim tekstovima. Međutim, brojnost, raznovrsnost, te znanstvena i stručna kvaliteta tekstova sadržanih u ovome "Zborniku" vrijedan su doprinos proučavanju ruralnog turizma u Hrvatskoj i svih njegovih segmenata. Također, oni mogu poslužiti kao osnova budućim istraživanjima ruralnog turizma, ali i svima onima koji se bave, ili će se baviti, ruralnim turizmom, te onima koji će, na svim razinama, promišljati i donositi odluke, planove, programe i strategije vezane za ruralni turizam. 